\title{
The determinants of advertising intensity in the brazilian manufacturing industry: an econometric study
}

Marcelo Resende Instituto de Economia, Universidade Federal do Rio de Janeiro

\section{Key-words}

advertising, structure-conductperformance.

JEL Classification L29, L60

\section{Palauras-chave}

propaganda, estrutura-condutadesempenho.

Classificação JEL L29, L60

\section{Abstract}

The paper econometrically investigates the determinants of advertising intensity in the manufacturing industry of São Paulo, Brazil in 1996 taking as reference an extensive survey carried out by Fundação SEADE. The preliminary investigation indicated a substantial degree of endogeneity in structure and performance variables. The instrumental variables estimation also considered instruments referring to information technology and organizational practices and indicated relevant roles for industrial concentration, barriers to entry, profitability and prevalence of durable goods in explaining advertising intensity. The results lend some support to an informative role of advertising in the Brazilian case.

\section{Resumo}

O trabalho investiga econometricamente os determinantes da intensidade de propaganda na indústria de transformação de São Paulo, Brasil em 1996 tomando como referência uma ampla pesquisa implementada pela Fundação SEADE. A investigação preliminar indicou um elevado grau de endogeneidade nas variáveis de estrutura e desempenho. A estimação por variáveis instrumentais considerou também instrumentos relacionados à tecnologia da informação e práticas organizacionais revelou papéis relevantes para a concentração industrial, barreiras à entrada, lucratividade e prevalência de bens duráveis na explicação da intensidade de propaganda. Os resultados fornecem algum suporte para um papel informativo da propaganda no caso brasileiro. 


\section{1_ Introduction}

Product differentiation is an important source of market power in many industries. In a related vein, different forms of non-price competition in terms of advertising and various forms of promotions are likely to play an important role in many markets characterized by imperfect competition, and indeed, may delineate a competition strategy that can complement usual price competition [see $e$.g. Slade (1995)].

The majority of the studies on advertising consider reduced form estimation under the structure-conductperformance (SCP) tradition. The competing views of advertising in terms of an informative or persuasive role in some cases produce distinct and detectable empirical implications. Overall, the evidence is somewhat mixed with reference to those aspects as indicated by Cable (1972), Strickland and Weiss (1976), Martin (1979a, 1979b), Gupta (1983), Uri (1988) and Gisser (1991), and as a rule, the results are not very conclusive in the case of developed countries.

In a more recent and promising approach, Ackerberg (2001) examines consumer-level data to distinguish different effects of brand advertising in non-durable experience goods in terms of either informative or prestige effects. The referred approach is prone to a more formal modeling of consumer learning as in Ackerberg (2003), but the data requirements are likely to be strong in those types of studies.

The present study investigates the determinants of advertising intensity in the manufacturing industry of São Paulo, Brazil. In fact, only a handful of contributions in terms of econometric studies in the SCP tradition were developed for the Brazilian case, as for example Braga (1979) and Macedo and Portugal (1995) and more recently the study of Lima and Resende (2004) in the conjectural variations tradition. However, the role of advertising was not addressed due to severe data availability constraints. This paper therefore attempts to contribute by considering the case of a developing country, and also by providing an initial examination of the role of modern organizational practices in that context. In fact, the former aspect has not been considered even in the related literature for developed countries.

The paper is organized as follows. The second section provides some basic background on the economic conceptual aspect of 
advertising and summarizes previous empirical evidence on the topic. The third section discusses the data construction procedures and presents the relevant empirical results. The fourth section concludes.

\section{2_Advertising:} some conceptual aspects

An influential branch of the literature has addressed the optimal choice of advertising intensity in the context of a monopolist. ${ }^{1}$ The seminal paper of Dorfman \& Steiner-DF (1954) included advertising expenses $(A)$ as a relevant demand shifter. Thus proceeding, one readily obtains from profit maximization the influential DF condition:

$\frac{A}{S}=\frac{\varepsilon_{A}}{\varepsilon}$

See Hay and Morris (1991) Martin (1993) and Ferguson and Ferguson (1994), for overviews on advertising. where $S$ denotes sales, and $\varepsilon_{A}$ and $\varepsilon$ respectively stand for the demand elasticity with respect to advertising expenditure and price. It is intuitively clear that advertising intensity should respond positively to the demand sensitivity to advertising expenses, and negatively to the sensitivity of demand to prices. A well known result is that the Lerner index for the monopolist is given by $L \equiv(p-M C) / p=1 / \varepsilon$, and therefore a positive association between advertising intensity and profitability will emerge from expression (3). This static formulation was generalized to a dynamic setting by Nerlove and Arrow (1962) and gives rise to a similar condition as provided by:

$\frac{A}{S}=\frac{\varepsilon_{A}}{\varepsilon(r+d)}$

where $r$ denotes the rate of discount and $d$ stands for the depreciation rate of the advertising capital. In addition to the effects of the static case, the longer-lived the effects of advertising, and the lower the rate at which future earnings are discounted, the higher the optimal advertising intensity will be. Even though these models consider a monopolistic setting, they provide an important benchmark. In fact, the DF condition emerges in the case of a colluding oligopoly as shown by Cowling (1972) [apud Ferguson and Ferguson (1994)].

The case of oligopoly is, of course, more complex as there will be strategic interdependence between the advertising policies of the different competitors and the most influential models, as for example Milgrom and 
Roberts (1986), consider a different perspective. Specifically, they focus on the possibility of advertising playing a role in signaling product quality. In fact, advertising campaigns with low informational content are pervasive and it is likely that expensive advertisements act as indirect quality signals.

The issue of information content is important if one considers the dichotomy between search goods and experience goods. The former refers to goods whose characteristics can be known before consumption whereas the latter category encompasses goods whose characteristics are gradually learnt by experience. These two categories are closely related to informative or persuasive roles of advertising, respectively.

Since the focus of this paper relies on the determinants of advertising, it is useful to consider how the usual explanatory variables considered in reduced-forms estimation within the SCP tradition affect advertising intensity in the informative view (IV) and persuasive view $(P V)$ of advertising.. A typical equation is as follows:

$$
\begin{aligned}
& P V: \quad+\quad++ \\
& \frac{A}{S}=f(C O N C, P M, B E) \\
& I V: \quad-/+\quad-/+\quad-
\end{aligned}
$$

where $C O N C, B E$ and $P M$ respectively denote concentration, profit margin and barriers to entry. Hay and Morris (1991) and Ferguson and Ferguson (1994) can provide some guidance on possible expected signs of the referred variables. The comparison between the two views and the related expected signs rely, strictly speaking, on expected associations with causalities that are not always clear cut. In fact, complex simultaneity effects are likely to be relevant and are the focus of the investigation of the present paper.

In the case of a persuasive role of advertising, barriers to entry play a central role in enabling market power as they are associated with brand loyalty.

Advertising creates a stronger preference for the established brand and the scope for stronger market dominance (and concentration) and therefore for the exercise of market power. The non-competitive effect may be stronger if there are economies of scale in advertising that confer cost advantages to larger firms. One would expect a positive association between advertising intensity and barriers to entry, concentration and profitability. ${ }^{2}$ In the informative view, a negative association between advertising intensity and barriers to entry is
2 As mentioned before, one can establish a positive association between advertising and profitabiility taking as reference the limiting case of the Dorfman-Steiner condition. Moreover, the classic work of Cowling and Waterson (1976) motivates positive association between profitability and concentration (as measured by the Herfindahl index) in the context of a Cournot oligopoly. 
expected. If the informational content of advertising is important, it might actually stimulate competition as often occurs with the announcement of price promotions. In contrast, the expected signs of the relationship with concentration and profitability, are possibly ambiguous, as the competition facilitation may give rise at a later moment to the dominance of the most efficient. This may not occur if there are no important efficiency differentials in the sector. It is possible, for example, that companies that best satisfy consumers' requirements may expand their market shares at the expense of their less efficient competitors and the market may become more concentrated, despite the effect of advertising in reducing barriers to entry. Below, we summarize the evidence obtained from previous studies works in Table 1.

Table 1_The Determinants of Advertising Intensity: Summary of Empirical Evidence

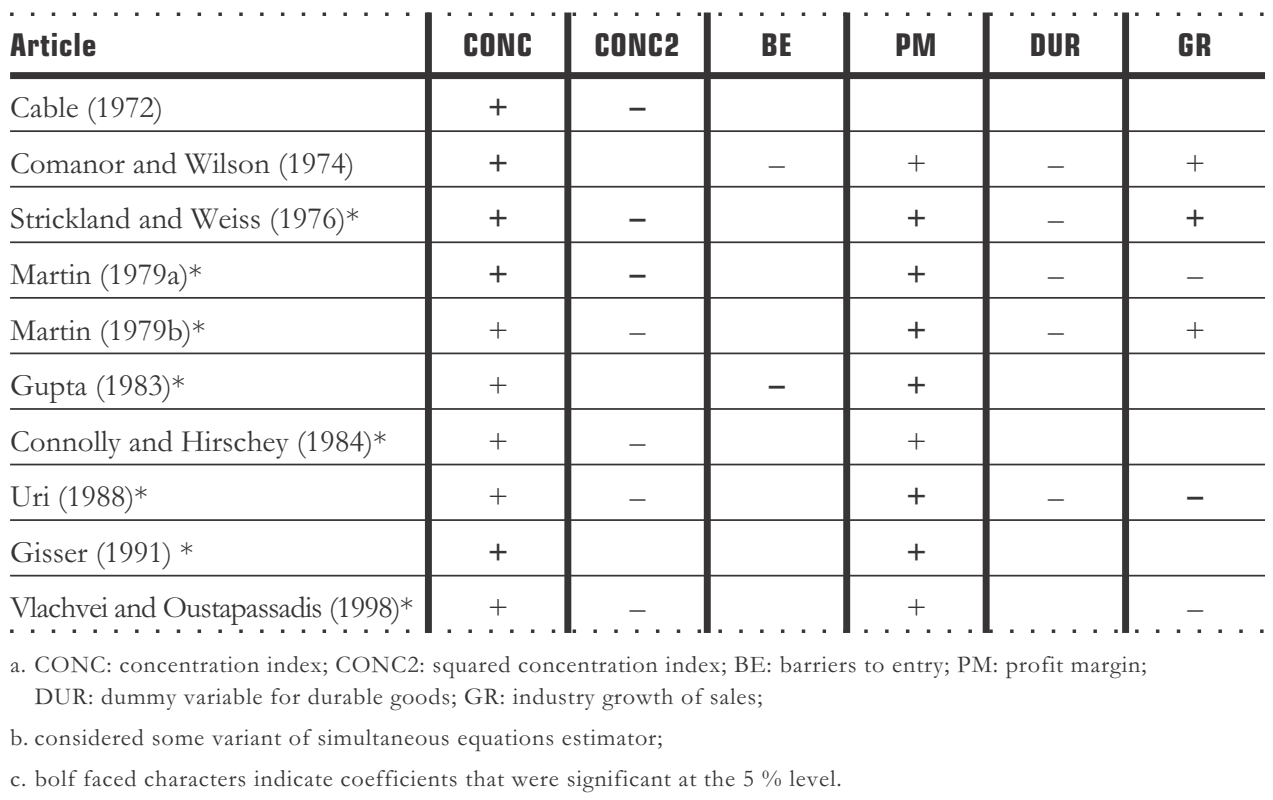


It is important to stress that besides the listed variables, other explanatory variables were occasionally considered, for example, variables referring to imports divided by industry sales and percentage of sales going to final consumer demand. The other variables seldom produced statistically significant coefficients. In the case of articles that considered different methods of estimation, we reported the results from the most sophisticated version. The stronger results refer to the positive effect of concentration and profit margin, as well as the negative effect of squared concentration. In fact, since at least Cable (1972), it has been proposed that a non-linear relationship between advertising intensity and concentration as the related effect would be stronger in the case of oligopolistic interdependence. ${ }^{3}$

The dummy variable for durables typically displayed the expected negative sign but always had a statistically insignificant coefficient. Indeed, the longer life of durable goods and the typical higher complexity of the goods stimulate consumers to search for alternative information and therefore these products would tend to be less responsive to advertising. This effect is understandable, given that typically the price of durable goods would be higher and any evaluation mistakes would imply higher welfare losses for the consumers. ${ }^{4}$

\section{3_Empirical analysis}

\section{1_Data source}

The basic data source of the study is the extended survey carried out by Fundação SEADE for firms in the state of São Paulo [Pesquisa de Atividade Econômica Paulista-PAEP]. Even though data is essentially available in terms of a cross-section for 1996 (with the exception of a few variables), it is worth mentioning the wealth of information in terms of organizational practices. This kind of information is rarely available and the same occurs with the advertising data used in this study. Our sample includes 9354 manufacturing firms classified at the 4-digit level after considering some omissions. This survey has mostly a census character, as that was the case with firms in São Paulo with headquarters in that state. For firms with headquarters situated outside the state, a sampling procedure was done for firms with at least 30 employees. In order to implement the survey, Fundação SEADE considered a list of firms from the Brazilian Institute of Geography and Statistics [IBGE] and administrative reports from the Ministry of Employment and Labor [Relação Annual de Informações Sociais-RAIS]. The former is a comprehensive and
3 The evidence for Brazil is very limited as no advertising equation was previously estimated. Braga (1979) considered the estimation of profitability equations within the SCP tradition and in the sectoral-level version had advertising intensity as explanatory variable. The coefficients were negative but not significant.

4 Keown et al. (1989) provide some evidence of lower advertising intensity in durable goods industries. 
reliable source for existing firms, since any formal enterprise is required to report basic information regarding employment and educational level of employees, or face a heavy fine. It is important also to stress that the segment of the sample that possesses a census character is highly dominant in the case of the PAEP industry questionnaire. In fact, the firms with headquarters in the state of São Paulo account for $81.5 \%$ of the employment of all firms established in that state according to the IBGE. Finally, the importance of the manufacturing industry in São Paulo with respect to Brazil as a whole is worth mentioning. Taking as reference information from the IBGE

[Pesquisa Industrial Annual-PIA-IBGE], in 1996, São Paulo had a participation of $51.57 \%$ relative to the total of Brazilian manufacturing industry when the criterion is value added. For total employment, the relevant figure is $48.71 \%$. The previous comments indicate that despite the sampling procedure present in part of the survey, the present data base appears to be representative of the manufacturing industry.

Table 2_Summary Statistics

\begin{tabular}{|c|c|c|c|c|}
\hline Variable & Minimum & Maximum & Mean & Std. deviation \\
\hline $\mathrm{ADV}$ & 0.00 & 0.49 & 3.79E-03 & $1.35 \mathrm{E}-02$ \\
\hline $\mathrm{CONC}$ & 0.00 & 1.00 & 0.1520 & 0.1664 \\
\hline $\mathrm{CD}$ & 0.00 & 1.00 & 0.2745 & $6.72 \mathrm{E}-02$ \\
\hline $\mathrm{PM}$ & -0.0682 & 0.6827 & $7.82 \mathrm{E}-03$ & 2.1944 \\
\hline DUR & 0 & 1 & 0.7108 & 0.4534 \\
\hline MICRO & 0.00 & 2.50 & $8.78 \mathrm{E}-02$ & 0.1304 \\
\hline TQM & 0 & 1 & 0.6501 & 0.4770 \\
\hline IJIT & 0 & 1 & 0.7886 & 0.4083 \\
\hline SC & 0 & 1 & 0.6610 & 0.4734 \\
\hline MES & 16 & 9687.71 & 154.7464 & 330.2899 \\
\hline EX & 0.20 & 55.40 & 14.6938 & 14.4474 \\
\hline IM & 0.20 & 82.20. & 19.0734. & 24.1480 \\
\hline
\end{tabular}


The previous Table presents the summary statistics. It becomes clear that the degree of heterogeneity is high in the sample. With respect to the advertising intensity, it is worth mentioning the large number of firms in the sample with zero or negligible advertisement effort. Among the sectors with high advertising intensity are, for example, traditional sectors such as manufacturing of electronic appliances (like TV sets), clothing, medications and alcoholic beverages, just to mention a few.

Additionally, Table A1 in the appendix presents pairwise-correlations for the variables considered in the study. Most of the correlations are statistically significant but with small or at most moderate magnitudes. Despite the caveats associated with bivariate correlations, we do not need to be concerned with colinearities across the different explanatory variables later used in the econometric analysis.

\section{2_ Empirical results}

In this sub-section, we report the results referring to the estimation of a reduced form equation for the determinants of advertising intensity in the Brazilian manufacturing industry in accordance with the following empirical specification:
$A D V=f\left(C O N C, C O N C^{2}, P M, C D, \varepsilon\right)$

where: ADV: adverting intensity as measured by advertising expenses divided by sales (net operational revenues);

CONC: concentration as measured by the Herfindahl index $H \equiv \sum_{i} S_{i}^{2}$ with $S_{i}$ standing for market shares;

$\mathrm{CONC}^{2}$ : the square of the aforementioned concentration index as motivated by the previously mentioned non-linearities; PM: profit margin as defined by $\frac{\text { gross value of production }}{\text { indirect consumption }+ \text { wages }}-1$

Even though less frequent, similar profitability measures have been used in the literature [see $e . g$. Rodrigues and Façanha (1992)]. ${ }^{5}$

_ CD: cost disadvantage as measured by percentage of employment in a given industry in firms below the minimum efficient scale (proxied by the average firm size in terms of the number of employees). The larger the proportion of firms operating in a suboptimal scale, the lower would be the cost disadvantage of those smaller

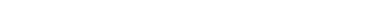

5 The choice of profitability measure largely reflected data availability but it is reassuring that structure-conductperformance relationships appear to be robust to alternative profitability measures as argued by Schmalensee (1989). 
6 Similar measures were considered by Mata and Machado (1996) and Görg and Strobl (2002) in the context of the determinants of firms' start-up size.

7 The estimated coefficients for the sectoral dummies were omitted for conciseness but can be provided upon request. scale firms. This variable can be thought of an inverse proxy for barriers to entry associated with scale effects. ${ }^{6}$

Additionally some variables will be used in the subsequent analysis:

_ DUR: dummy variable that assumes value 1 if the firm is in a sector characterized by durable goods and 0 otherwise. One would expect in principle a less important role for advertising in the case of durable goods as price competition would become more important;

_EX: export intensity defined as exports divided by apparent consumption as provided at the 3-digit level by Moreira (1999), calculated upon data from the SRF-Ministry of Finance, Brazil. This variable indicates, in part, whether the firm belongs to a dynamic exporting sector;

_ MICRO: number of microcomputers per employee; _ TQM: dummy variable that assumes value 1 if the firm had a total quality management program and 0 otherwise;
_IJIT: dummy variable that assumes value 1 if the firm had an internal just-in-time program and 0 otherwise;

_ SC: dummy variable that assumes value 1 if the firm had a program for statistical control of processes and 0 otherwise;

It is worth mentioning the less conventional variables that are listed above. First we can observe proxies for the information technology (IT) capital as indicated by MICRO. Second, we can pinpoint variables referring to the prevalence of modern organizational practices that would define an intangible organizational capital. Those variables will be useful as instruments later on in the estimation. In fact, an important challenge in more careful studies on the structure-conduct-performance (SCP) tradition is the availability of relevant instruments. All estimated models considered sectoral dummy variables at the 3 -digit level (87 variables). This strategy is important to control for unobserved sectoral heterogeneity and revealed to be important. In fact, in the final estimated model using instrumental variables, $62.07 \%$ of the coefficients of those sectoral dummies were significant at the $5 \%$ level. $^{7}$ 


\section{3_Empirical results}

Empirical implementation considered common specifications encountered in the literature that are referred to explanatory variables for advertising intensity: concentration, squared concentration, profit margin and a proxy for barriers to entry. The initial results are summarized in Table 3 which at first considered a simple ordinary least squares regression that ignored potential endogeneities in structure and performance variables.
In fact, part of the empirical literature adopted this questionable approach and therefore ignored the recent literature that emphasized the endogenous character of market structure [see e. g. Sutton (1991)]. ${ }^{8}$ In fact, we consider Hausman's endogeneity tests to assess the presence of such effects in terms of the variables CONC, $\mathrm{CONC}^{2}$ and PM. ${ }^{9}$ The referred procedure involves the consideration of an auxiliary regression of the potentially endogenous variables against the variables justified in the literature.

Table 3_ Determinants of advertising intensity: preliminary estimation and exogeneity tests

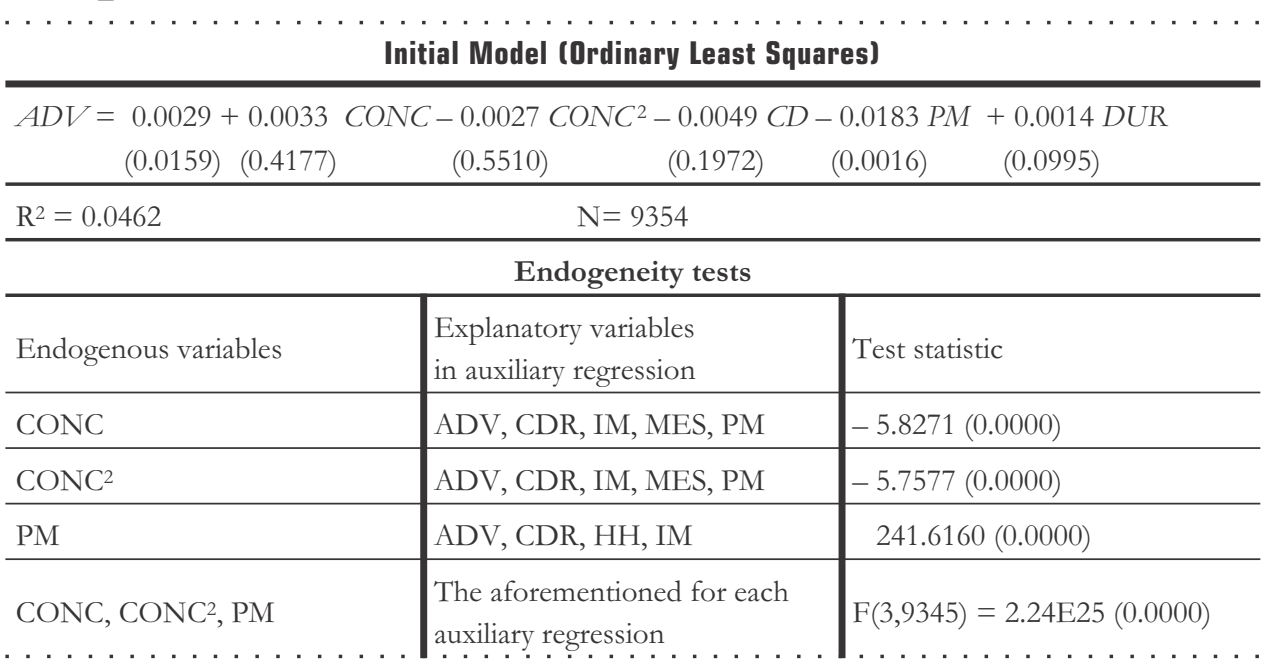

Note: The estimation considered White heteroskedasticity consistent standard errors, and p-values appear in parentheses.
8 The estimations were

implemented with the software Eviews 4.1

9 See Hausman (1978). 
${ }_{10}$ Given the large sample size one can consider a standard Normal distribution in the individual test.
In a second stage the residual of this auxiliary regression is added in the original equation for advertising intensity and a standard t test is applied to its coefficient or yet a $\mathrm{F}$ test based on the inclusion of the three residuals as additional explanatory variables in the advertising equation. ${ }^{10}$ We considered both approaches and the evidence suggested an overwhelming rejection of the hypothesis of exogeneity of the variables $\mathrm{CONC}, \mathrm{CONC}^{2}$ and $\mathrm{PM}$ and therefore one should consider instrumental variables methods to account for endogeneities.

Next, estimation is made with a two stage least squares -2SLS type estimator. The instruments chosen were the exogenous variables used in the main advertising equations and in the auxiliary equations and the IT, training and organizational variables mentioned in the previous section. The results are presented in Table 4.

It is important to stress that the choice of instruments can have impact on the results; in particular the roles of EX that expresses the export dynamism of the sector and yet SC. Since statistical control of process programs are likely to have a more long term implementation cycle, one can be reasonably confident of the exogenous character of that variable.

Table 4_ Determinants of Advertising Intensity - Final Model (Two Stages Least Squares)

\begin{tabular}{|c|c|c|}
\hline Variable & Coefficient & p-value \\
\hline Constant & -0.0634 & 0.0041 \\
\hline CONC & 0.2746 & 0.0276 \\
\hline $\mathrm{CONC}^{2}$ & -0.1360 & 0.4501 \\
\hline $\mathrm{CD}$ & 0.1109 & 0.0000 \\
\hline PM & -1.0899 & 0.0247 \\
\hline DUR & 0.0291 & 0.0003 \\
\hline
\end{tabular}

Sargan's test: $\chi^{2}(1)=0.1093$ ( $p$-value: 0.7409$)$

Instruments: Constant, CDR, DUR, EX, MES, IJIT, TQM, SC, MICRO

Note: The estimation considered White heteroskedasticity consistent standard errors. 
Sargan's test for the validity of the instruments is also considered and provides evidence for the non-rejection of the null hypothesis of validity of the chosen instruments. The test statistic is given by $(N-k)$ times the uncentered $\mathrm{R}^{2}$ from the regression of the residuals of instrumental variables estimation on all instruments, where $N$ denotes the number of observations and $k$ the number of estimated parameters. Under the null hypothesis of validity of instruments the statistic is distributed as a chi-square with degrees of freedom equal to the number of instruments in excess of the minimum necessary for identification. ${ }^{11}$

The most robust results for significant coefficients that emerge from different specifications refer the effects of concentration and barrier to entry that were in accordance with the previous literature. ${ }^{12}$ The squared concentration coefficient, on the other hand, had the usual negative signal but its coefficient was not significant. Finally, a significant negative effect were detected for the profit margin and the dummy variable for durables. The negative sign for PM could emerge in an informative setting, though in the previous literature a positive sign is more prevalent. In that sense, the only unexpected effect relates to the dummy for durables, but might reflect the approximation involved in the classification of the products.

In summary, the results expected from the literature are partially supported and the signs obtained provide some evidence for an informative role of advertising.

\section{Final Comments}

The paper investigated the determinants of advertising intensity in the manufacturing industry of São Paulo, Brazil in 1996. The effort was valuable given the lack of similar studies for developing countries like Brazil and also for the unusual availability of detailed organizational data in the data source used in this study.

As expected, the results indicated a high degree of endogeneity in the structure and performance variables. The estimation, made with a variant of the instrumental variables estimator, detected a decisive role for industrial concentration in explaining advertising intensity but not a significant quadratic term that would indicate a non-linear association. Moreover, the inverse
11 The uncentered

$\mathrm{R}^{2}=1-\left(\frac{\sum_{i} e_{i}^{2}}{\sum_{i} y_{i}^{2}}\right)$ where $e$

stands for the residual from the auxiliary regression having the IV residual as dependent variable and $y$ denotes the IV residual from the previous estimation, see Davidson and MacKinnon (1993).

12 It would be desirable to be able to proxy barriers to entry with more directly related to brand loyalty. In fact, previous empirical work (and even the present one) focused on measures related to absolute cost advantages, though different types of barriers to entry often prevail in a given sector. 
measure for barriers to entry displayed the expected effect and a significant negative effect associated with the profit margin variable (PM) was detected. The negative effect accruing from the dummy variable for durables (DUR) is, however, less intuitive.

In any case, the natural route for future associated research refers to the estimation of an explicit simultaneous system comprising equations for advertising, profitability and industrial concentration. In that context, not only could the results that emerge for a developing country be relevant, but a careful exploration of the effects of modern organizational practices may also produce some interesting new insights. Additionally, it would be relevant to extrapolate the limited cross-sectional context and consider panel data sets that conveniently allow control for firm-level unobserved hetoregeneity. 


\section{References}

ACKERBERG, D. A. Empirically distinguishing informative and prestige effects of advertising. RAND Journal of Economics, n. 32, p. 316-333, 2001 .

ACKERBERG, D. A.

Advertising, learning and consumer choice in experience good markets: an empirical examination. International Economic Review, n. 44, p. 1007-1040, 2003.

BRAGA, H. C. Determinantes do desempenho da indústria brasileira: uma investigação econométrica. Revista Brasileira de Economia, n. 33, p. 501-570, 1979.

CABLE, J. market structure, advertising policy and interindustry differences in advertising intensity. In: COWLING, K. (Ed.). market structure and corporate behavior: theory and empirical analysis of the firm. London: Grey-Mills, p. 105-124, 1972.

COMANOR, W. S.; WILSON, T. A. Advertising and Market Power. Cambridge-MA: Harvard University Press, 1974.

CONNOLLY, R. A.; HIRSCHEY, M. R\&D, market structure and profits: a value-added approach. Review of Economics and Statistics, p. 682-686, 1984.
COWLING, K. Market structure and corporate behavior: theory and empirical analysis of the firm. London: Gray-Mills, 1972.

COWLING, K., WATERSON, M. Price-Cost margins and market structure. Economica, n. 41, p. 267-274, 1976.

\section{DAVIDSON, R.;}

MACKINNON, J. G. Estimation and inference in econometrics. Oxford. Oxford University Press, p. 232-237, 1993.

EVANS, W. N.; FROEB, N. WERDEN, G. J. Endogeneity in the concentration-price relationship: causes, consequences, and cures. Journal of Industrial Economics, n. 41, p. 431-38, 1993.

FERGUSON, P. R.; FERGUSON, G. J. Industrial economics: issues and perspectives. London: MacMillan, 1994.

GABEL, H. L. A simultaneous equation analysis of the structure and performance of the United States petroleum refining industry. Journal of Industrial Economics, n. 28, p. 89-104, 1979.
GEROSKI, P. A. Simultaneous equations models in the structure-performance paradigm. European Economic Review, n. 19, p. 145-158, 1982.

Gisser, M. Advertising, concentration and profitability in manufacturing. Economic Inquiry, p. 148-165, 1991.

GÖRG, H.; STROBL, E. Multinational companies and entrant start-up size: evidence from quantile regressions.

Review of Industrial Organization, $\mathrm{n}$. 20, p. 15-31, 2002

GUPTA, V. K. A simultaneous determination of structure, conduct and performance in canadian manufacturing. Oxford Economic Papers, n. 35, p. 281-301, 1983.

HAY, D. A.; MORRIS, D. J.

Industrial economics and organization. Oxford: Oxford University Press, 1991.

HAUSMAN, J. Specification tests in econometrics. Econometrica, n. 46, p. 1251-1271, 1978.

KEOWN, C. E.; SYNODINOS, N. E.; JACOBS, L.W., WORTHLEY, R. Transnational advertising-to-sales ratios: do they follow the rules? International Journal of Advertising, n. 8, p. 375-382, 1989.
LIMA, M. A. M.; RESENDE, M. Profit margins and business cycles in brazilian industry: a panel data study. Applied Economics, n. 36, p. 923-930, 2004.

MACEDO, P. B.; PORTUGAL, S. S. Estrutura de mercado e desempenho na indústria brasileira. Revista Brasileira de Economia, n. 49, p. 685-695, 1995. MARTIN, S. Advertising, concentration, and profitability: the simultaneity problem. Bell Journal of Economics, n. 10, p. 639-647, 1979a

MARTIN, S. Entry barriers, concentration, and profits. Southern Economic Journal, n. 46, p. $471-488,1979 \mathrm{~b}$

MARTIN, S. Advanced industrial economics. Oxford: Blackwell Publishers, 1993.

MATA, J.; MACHADO, J. A. F. Firm start-up size: a conditional quantile approach, European Economic Review, n. 40, p. 1305-1323, 1996.

MILGROM, P.; ROBERTS, J. Price and advertising as signals of product quality. Journal of Political Economy, n. 94, p. 796-821, 1986. 
MOREIRA, M. M. A indústria brasileira nos anos 90. Que já se pode dizer? In: GIAMBIAGI, F.; MOREIRA, M. M. (Eds.). A economia brasileira nos anos 90. Rio de Janeiro: BNDES, 1990. p. 293-332.

NERLOVE, M.; ARROW, K. J. Optimal advertising policy under dynamic conditions. Economica, n. 29 , p. $129-142,1962$.

RODRIGUES, D. A.

FACANHA, L. O. Indústria

brasileira na década de 70

interpretação de resultados de estatística multivariada e de aspectos da dinâmica concorrencial. Revista Brasileira de Economia, n. 46, p. 447-476, 1992.

SCHMALENSEE, $\mathrm{R}$.

Inter-industry studies of structure and performance. In:

SCHMALENSEE, R.; WILLIG,

R. D. (Eds.). Handbook of Industrial

Organization, Amsterdam:

North-Holland, 1989

p. 951-1009.

SHERMAN, R.; TOLLISON, R. Advertising and profitability.

Review of Economics and Statistics, n. 53 , p. $397-407,1971$

SLADE, M. E. Product rivalry with multiple strategic weapons: an analysis of price and advertising competition. Journal of Economics and Management Strategy, n. 4, p. 445-476, 1995.

STRICKLAND, A.D.; WEISS, L. W. Advertising, concentration, and price-cost margins. Journal of Political Economy, n. 84, p. 1109-1121, 1976
SUTTON, J. Sunk costs and market structure. Cambridge-MA: MIT Press, 1991.

THOMPSON, S. Internal organization and profit: a note. Journal of Industrial Economics, n. 30, p. 201-211, 1981 .

URI, N. D. A Re-examination of the relationship between industry structure and economic performance. Applied Economics, n. 20 , p. $1383-1400,1988$.

VLACHVEI, A.

OUSTAPASSADIS, $\mathrm{K}$

Advertising, concentration and profitability in Greek food manufacturing industries. Agricultural Economics, n. 18, p. 191-198, 1998.

- The author acknowledges

- research assistance from Pedro

- Mendonca and Arthur Jóia, and:

- financial support from CNPq.

- Finally, comments from two

- anonymous referees were useful

- for improving the paper, but the - usual caveats apply.

Authors' e-mail

. mresende@ie.ufrj.br

ceived on April 2005;

accepted on July 2006.

............... 
Table A1_Correlations across variables

\begin{tabular}{|c|c|c|c|c|c|c|c|c|c|c|c|c|}
\hline & ADV & CONC & CD & PM & DUR & MICRO & TQM & IJIT & SC & MES & EX & IM \\
\hline $\mathrm{ADV}$ & 1.000 & $\begin{array}{c}0.045 \\
(0.000)\end{array}$ & $\begin{array}{l}-0.055 \\
(0.000)\end{array}$ & $\begin{array}{r}-0.030 \\
(0.004)\end{array}$ & $\begin{array}{l}-0.043 \\
(0.000)\end{array}$ & $\begin{array}{c}0.110 \\
(0.000)\end{array}$ & $\begin{array}{r}-0.044 \\
(0.000)\end{array}$ & $\begin{array}{l}-0.065 \\
(0.000)\end{array}$ & $\begin{array}{r}-0.082 \\
(0.000)\end{array}$ & $\begin{array}{c}0.054 \\
(0.000)\end{array}$ & $\begin{array}{r}-0.020 \\
(0.049)\end{array}$ & $\begin{array}{c}0.025 \\
(0.017)\end{array}$ \\
\hline CONC & & 1.000 & $\begin{array}{r}-0.463 \\
(0.000)\end{array}$ & $\begin{array}{r}-0.005 \\
(0.601)\end{array}$ & $\begin{array}{r}-0.242 \\
(0.000)\end{array}$ & $\begin{array}{c}0.148 \\
(0.000)\end{array}$ & $\begin{array}{c}-0.027 \\
(0.000)\end{array}$ & $\begin{array}{r}-0.045 \\
(0.000)\end{array}$ & $\begin{array}{r}-0.050 \\
(0.000)\end{array}$ & $\begin{array}{c}0.267 \\
(0.000)\end{array}$ & $\begin{array}{c}0.002 \\
(0.880)\end{array}$ & $\begin{array}{c}0.189 \\
(0.000)\end{array}$ \\
\hline $\mathrm{CD}$ & & & 1.000 & $\begin{array}{c}0.020 \\
(0.053)\end{array}$ & $\begin{array}{c}0.153 \\
(0.000)\end{array}$ & $\begin{array}{r}-0.094 \\
(0.000)\end{array}$ & $\begin{array}{c}0.055 \\
(0.000) \\
\end{array}$ & $\begin{array}{c}0.068 \\
(0.000)\end{array}$ & $\begin{array}{c}0.083 \\
(0.000)\end{array}$ & $\begin{array}{r}-0.318 \\
(0.000)\end{array}$ & $\begin{array}{r}-0.060 \\
(0.000)\end{array}$ & $\begin{array}{r}-0.145 \\
(0.000)\end{array}$ \\
\hline PM & & & & 1.000 & $\begin{array}{c}0.039 \\
(0.000) \\
\end{array}$ & $\begin{array}{c}0.015 \\
(0.161) \\
\end{array}$ & $\begin{array}{c}0.008 \\
(0.461) \\
\end{array}$ & $\begin{array}{c}0.016 \\
(0.120) \\
\end{array}$ & $\begin{array}{c}0.027 \\
(0.010) \\
\end{array}$ & $\begin{array}{l}-0.017 \\
(0.110) \\
\end{array}$ & $\begin{array}{l}-0.033 \\
(0.002) \\
\end{array}$ & $\begin{array}{r}0.035 \\
(0.001) \\
\end{array}$ \\
\hline DUR & & & & & 1.000 & $\begin{array}{r}-0.046 \\
(0.000)\end{array}$ & $\begin{array}{c}0.025 \\
(0.014)\end{array}$ & $\begin{array}{c}0.031 \\
(0.002)\end{array}$ & $\begin{array}{c}0.083 \\
(0.000)\end{array}$ & $\begin{array}{l}-0.016 \\
(0.000)\end{array}$ & $\begin{array}{c}0.140 \\
(0.000)\end{array}$ & $\begin{array}{c}0.188 \\
(0.000)\end{array}$ \\
\hline MICRO & & & & & & 1.000 & $\begin{array}{l}-0.137 \\
(0.000)\end{array}$ & $\begin{array}{r}-0.109 \\
(0.000)\end{array}$ & $\begin{array}{c}-0.144 \\
(0.000)\end{array}$ & $\begin{array}{c}0.045 \\
(0.000)\end{array}$ & $\begin{array}{l}-0.036 \\
(0.000)\end{array}$ & $\begin{array}{c}0.223 \\
(0.000)\end{array}$ \\
\hline TQM & & & & & & & 1.000 & $\begin{array}{c}0.322 \\
(0.000)\end{array}$ & $\begin{array}{c}0.494 \\
(0.000) \\
\end{array}$ & $\begin{array}{l}-0.062 \\
(0.000)\end{array}$ & $\begin{array}{c}0.020 \\
(0.049)\end{array}$ & $\begin{array}{r}-0.043 \\
(0.000)\end{array}$ \\
\hline IJIT & & & & & & & & 1.000 & $\begin{array}{c}0.345 \\
(0.000)\end{array}$ & $\begin{array}{l}-0.047 \\
(0.000)\end{array}$ & $\begin{array}{c}0.013 \\
(0.194)\end{array}$ & $\begin{array}{l}-0.060 \\
(0.000)\end{array}$ \\
\hline SC & & & & & & & & & 1.000 & $\begin{array}{l}-0.091 \\
(0.000) \\
\end{array}$ & $\begin{array}{c}0.034 \\
(0.001) \\
\end{array}$ & $\begin{array}{l}-0.007 \\
(0.474) \\
\end{array}$ \\
\hline MES & & & & & & & & & & 1.000 & $\begin{array}{r}-0.008 \\
(0.455)\end{array}$ & $\begin{array}{r}-0.025 \\
(0.017)\end{array}$ \\
\hline EX & & & & & & & & & & & 1.000 & $\begin{array}{c}0.159 \\
(0.000)\end{array}$ \\
\hline IM & & & & & & & & & & & & 1.000 \\
\hline
\end{tabular}

Note: $p$-values are indicated in parentheses. 